\title{
PEMETAAN KEMAMPUAN PEMECAHAN MASALAH DAN KECEMASAN MATEMATIKA
}

\author{
Fatya Azizah ${ }^{1}$, Hartono ${ }^{2}$ \\ 1,2 Pendidikan Matematika, Universitas Negeri Yogyakarta \\ E-mail: fatyaazizah9@ gmail.com ${ }^{\text {1) }}$ \\ hartono@uny.ac.id ${ }^{2}$
}

Received 3 October 2018; Received in revised form 11 November 2018; Accepted 26 December 2018

\begin{abstract}
Mathematical problem solving skills are very important for our daily life because we know that the process of solving mathematical problems is a thought process that leads to new and useful results. One factor that causes mathematical difficulties is math anxiety. The solution to a problem depends on how the problem occurs, so that more in-depth research is needed regarding the corellation between problem solving skill and mathematical anxiety. This study aims to describe the mapping of problem solving abilities of eighth grade students of Junior High School in Banjarbaru. This research is a survey research with a subject consisting of 376 VIII junior high school students from 15 schools determined by stratified random sampling. The instrument used was a test of problem solving skill and a mathematical anxiety questionnaire. Data analysis was carried out by profile analysis. The mapping results show that there are still mathematical problem-solving skill and math anxiety average in schools in Banjarbaru that are not in accordance with accreditation status and existing theories. The summary of this study is that mathematics problem-solving and mathematics anxiety were not only affected by school accreditation status, but also many other factors that could not be mentioned one by one.
\end{abstract}

Keywords: Mapping; Mathematics Anxiety; Mathematics Problem-Solving.

PENDAHULUAN

Kemampuan

pemecahan

masalah dianggap sebagai jantung dari pembelajaran matematika karena kemampuan ini tidak hanya berguna untuk mata pelajaran tersebut, tetapi juga menekankan pada peningkatan kemampuan berpikir (Pimta et al, 2009: 381). Lester dan Kehle dalam Kramarski (2009: 138), mencirikan kemampuan pemecahan masalah matematika sebagai sebuah kegiatan yang meliputi keterlibatan siswa dalam berbagai kegiatan kognitif: diantaranya mengaitkan dan menggunakan pengetahuan dan pengalaman yang sudah dimiliki sebelumnya. Walaupun demikian, menurut hasil Programme for International Student Assesment (PISA) dan Trends in International Mathematics and Science Study (TIMSS) kemampuan pemecahan masalah pelajar Indonesia masih rendah.
Survey PISA (2015: 5) menunjukkan bahwa Indonesia mendapatkan peringkat ke 64 dari 72 negara peserta, sedangkan survey TIMSS terakhir tahun 2015 menunjukkan bahwa Indonesia mendapatkan peringkat ke 45 dari 50 negara.

Dibalik pentingnya kemampuan pemecahan masalah matematika tersebut, tentunya ada beberapa masalah yang tidak bisa dihindarkan. Sesuai dengan pernyataan Mohd dan Mahmood (2011: 1857) matematika merupakan pelajaran yang penting bagi siswa. Bagaimanapun, masih ada banyak siswa yang kesulitan dalam mempelajari matematika. Terkait adanya kesulitan dalam mempelajari matematika ini, Ramirez et al (2016: 83-84) berpendapat bahwa kecemasan matematika menjadi semakin tinggi saat kemampuan siswa dalam mempelajari matematika semakin rendah. $\mathrm{Al}$

\section{4 | AKSIOMA}


Mutawah (2015: 242) memberikan data TIMSS yang menyatakan bahwa siswa secara umum hampir terbagi menjadi dua berdasarkan ungkapan kepercayaan dirinya terhadap matematika yaitu $45 \%$ yang menyatakan kepercayaan diri dan $55 \%$ yang menyatakan ketidakyakinan atau kecemasan.

$$
\text { Penyelesaian suatu masalah }
$$

sangat bergantung pada bagaimana masalah yang terjadi. Jika masalah kecemasan matematika ini menyebabkan rendahnya kemampuan matematika siswa, maka solusi yang diberikan oleh Hambree (1990) dalam Foley (2017: 56) adalah agar orangtua dan guru ikut serta dalam penanganan kecemasan matematika siswa, mengerti mekanisme bagaimana kecemasan sehingga mempengaruhi kemampuan matematika siswa, hal ini bisa sangat membantu dalam mengurangi kecemasan matematika siswa, yang tentu akan berdampak pula pada kemampuan matematikanya. Namun, jika yang terjadi adalah sebaliknya, yaitu masalah kecemasan matematika disebabkan oleh rendahnya kemampuan matematika siswa maka solusi yang diberikan tentunya juga berbeda.

Terdapat beberapa penelitian sebelumnya yang meneliti kemampuan pemecahan masalah dan kecemasan matematika. Karasel (2009) meneliti mengenai hubungan kemampuan pemecahan masalah dan kecemasan matematika, Furner dan Marinas (2016) meneliti mengenai usaha mengurangi kecemasan matematika, serta Beilock dan Maloney (2015) meneliti mengenai dampak dari kecemasan matematika. Belum banyak penelitian yang meneliti lebih mendalam mengenai kemampuan pemecahan masalah dan kecemasan matematika secara lebih mendalam dengan metode kualitatif.

Berdasarkan uraian mengenai masalah kemampuan matematika khususnya kemampuan pemecahan masalah matematika dan kecemasan matematika di atas, serta pentingnya hal ini untuk diketahui dengan kurangnya informasi mengenai hal ini, maka perlu untuk mengetahui bagaimana pemetaan dari hubungan yang terjadi antara kemampuan pemecahan masalah dan faktor-faktor yang mempengaruhi kedua variabel tersebut. Dengan adanya penelitian ini, diharapkan salah satu masalah pendidikan di Indonesia dapat dipahami dan dapat menjadi sumber informasi untuk perbaikan system pendidikan di masa depan.

\section{METODE PENELITIAN}

Berdasarkan tujuan penelitian, jenis penelitian ini adalah penelitian survei. Penelitian survei adalah penelitian yang dilakukan dengan populasi besar dan sampel untuk menyamaratakan hasil penelitian.

Penelitian ini dilaksanakan di Kota Banjarbaru pada bulan FebruariApril 2018. Populasi dalam penelitian ini adalah siswa kelas VIII SMP di Kota Banjarbaru. Ada 36 Sekolah Menengah Pertama di Kota Banjarbaru dengan jumlah siswa adalah 4294. Sekolah Menengah Pertama yang terakreditasi di Kota Banjarbaru adalah 22 sekolah, SMP yang terakreditasi B adalah enam sekolah, sedangkan SMP yang tidak terakreditasi $\mathrm{C}$ tidak ditemukan dan sekolah tidak Status terakreditasi berjumlah delapan sekolah.

Berdasarkan perhitungan dari rumus Slovin dengan tingkat presisi 5\%, diperoleh sampel minimal 366 siswa. Diketahui bahwa rata-rata siswa dalam satu buah kelas di Banjarbaru adalah 25 siswa, sehingga akan dipilih setidaknya sekitar 15 dari 36 sekolah di Kota Banjarbaru untuk menjadi sampel dalam penelitian ini. Sekolah-sekolah yang dipilih sebagai sampel terdiri dari sembilan sekolah dengan akreditasi A, 
tiga sekolah dengan akreditasi $\mathrm{B}$, dan tiga sekolah yang tidak terakreditasi. Dari 15 sekolah ini didapat sampel sebesar 376 siswa.

Teknik sampling proporsional (proportional sampling) digunakan untuk menentukan sampel secara proporsional untuk setiap strata.

Teknik pengumpulan data yang dilakukan dalam penelitian ini adalah tes dan kuesioner yang diberikan sekaligus serta observasi. Pengumpulan data untuk mengukur kemampuan pemecahan masalah diperoleh dengan menggunakan 5 masalah esai dengan materi semester pertama di kelas VIII. Pengukuran kecemasan matematika siswa akan dilakukan dengan memberikan kuesioner dengan skala 15 , dengan butir pernyataan positif dan negatif.

Uji validitas tes pemecahan masalah menggunakan validitas isi (validitas isi). Angket kecemasan matematika menggunakan validitas isi dan validitas konstruk dengan analisis faktor.

Menganalisis skor kemampuan pemecahan masalah dan kecemasan matematika menggunakan statistika deskriptif berupa rata-rata. Membuat pemetaan antara kemampuan pemecahan masalah matematika dan kecemasan matematika siswa menggunakan analisis profil.

\section{HASIL PENELITIAN DAN PEMBAHASAN}

Peta akan berbentuk koordinat kartesius dengan sumbu $x$ merupakan sumbu kemampuan pemecahan masalah matematika siswa sampel di Kota Banjarbaru, sedangkan sumbu $y$ merupakan sumbu kecemasan matematika siswa sampel di Kota Banjarbaru. Titik koordinat tiap sekolah akan terbentuk dari rata-rata skor kemampuan pemecahan masalah sekolah yang bersangkutan dikurang dengan rata-rata kecemasan matematika siswa sampel di Kota Banjarbaru sebagai absis dan rata-rata kecemasan matematikanya dikurang dengan ratarata kemampuan pemecahan masalah matematika siswa sampel di Kota Banjarbaru sebagai ordinat. Data-data tersebut dapat dilihat pada Tabel 1.

Tabel 1. Titik-Titik pada Peta Hubungan

Kemampuan Pemecahan

Masalah dan Kecemasan

Matematika Siswa di Kota

Banjarbaru

\begin{tabular}{ccccc}
\hline Nama & Sumbu & Sumbu & \multirow{2}{*}{ Absis } & Ordinat \\
Sekolah & $x$ & $y$ & & \\
\hline A & & & 0,89 & $-2,4$ \\
B & & & 3,34 & $-0,27$ \\
C & & & 0,7 & 0,18 \\
D & & & $-3,51$ & 0,99 \\
E & & & 0,05 & 1,91 \\
F & & & $-4,76$ & 1,62 \\
G & & & 1,42 & $-2,09$ \\
H & 17,30 & 20,59 & $-3,67$ & 4,66 \\
I & & & 5,81 & $-0,13$ \\
J & & & $-2,76$ & $-0,67$ \\
K & & & $-2,07$ & $-0,66$ \\
L & & & $-2,51$ & 0,52 \\
M & & & $-2,13$ & 0,41 \\
N & & & 1,49 & $-1,59$ \\
O & & & 1,58 & $-1,05$ \\
\hline
\end{tabular}

Berdasarkan Tabel 1, dapat dibuat sebuah peta hubungan antara kemampuan pemecahan masalah dan kecemasan matematika siswa di Kota Banjarbaru sebagai berikut.

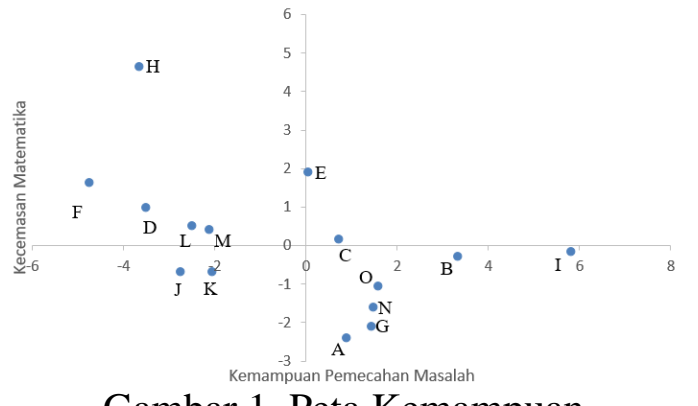

Gambar 1. Peta Kemampuan

Pemecahan Masalah dan Kecemasan Matematika

\section{6 | AKSIOMA}


Secara teori dan hasil penelitian yang telah dijelaskan sebelumnya, seharusnya tidak ada sekolah yang terdapat pada kuadran I dan III karena pada kuadrankuadran tersebut kemampuan pemecahan masalah matematika berbanding lurus dengan kecemasan matematika siswa.

Pada kuadran II kemampuan pemecahan masalah matematika berbanding terbalik dengan kecemasan matematika siswa, kuadran ini sudah sesuai dengan hasil pengujian yang telah dilakukan. Sekolah-sekolah pada kuadran II menggambarkan keadaan dimana siswa-siswa pada sekolah tersebut memiliki kemampuan pemecahan masalah yang rendah serta kecemasan matematika yang tinggi. Sekolah-sekolah yang berdasarkan teori seharusnya mengisi kuadran II adalah sekolah-sekolah yang tidak terakreditasi, yaitu sekolah $\mathrm{M}, \mathrm{N}$, dan O.

Pada kuadran IV kemampuan pemecahan masalah matematika juga berbanding terbalik dengan kecemasan matematika siswa, kuadran ini juga sudah sesuai dengan hasil pengujian yang telah dilakukan. Sekolah pada kuadran IV menggambarkan keadaan dimana siswa-siswa pada sekolah tersebut memiliki kemampuan pemecahan masalah yang tinggi serta kecemasan matematika yang rendah. Sekolah-sekolah yang berdasarkan teori seharusnya mengisi kuadran IV adalah sekolah-sekolah dengan status akreditasi A, yaitu sekolah A, B, C, D, E, F, G, H, dan I.

Sekolah dengan status akreditasi B seperti sekolah J, K, dan L, secara teori masih bisa terdapat pada kuadran II dan IV karena memiliki kemampuan pemecahan masalah dan kecemasan matematika yang menengah, mendekati titik $(0,0)$.
Dengan adanya beberapa sekolah yang menempati kuadran yang tidak sesuai dengan status akreditasinya, maka dapat disimpulkan bahwa di Banjarbaru masih ada sekolah yang memiliki kemampuan pemecahan masalah dan kecemasan matematika yang tidak sesuai dengan akreditasi dan teori yang ada.

Dalam penelitian ini terdapat perbedaan pemetaan sekolah antara teori dan fakta di lapangan pada banyak sekolah yang ada di Kota Banjarbaru. Perbandingan letak sekolah-sekolah di Kota Banjarbaru pada peta kemampuan pemecahan masalah dan kecemasan matematika antara teori dan fakta dapat dilihat pada Tabel 2.

Tabel 2. Perbandingan Teori dan Fakta Letak Sekolah pada Peta Kemampuan Pemecahan Masalah dan Kecemasan Matematika

\begin{tabular}{ccccc}
\hline \multirow{2}{*}{ No. } & \multirow{2}{*}{ Kuadran } & \multicolumn{2}{c}{ Sekolah } & \multirow{2}{*}{ Perbedaan } \\
\cline { 3 - 4 } & Teori & Fakta & \\
\hline 1 & I & - & C, E & C, E \\
& & M, & D, F, & \\
2 & II & N, O, & H, L, & D, F, H \\
& & (J, K, & M & \\
& & L) & & \\
3 & III & - & J, K & J, K \\
& & A, B, & & \\
& & C, D, & A, B, & \\
4 & IV & E, F, & G, I, & N, O \\
& & G, H, & N, O & \\
& & I, (J, & & \\
& & K, L) &
\end{tabular}

Secara teori dan hasil penelitian yang telah dijelaskan sebelumnya, seharusnya tidak ada sekolah yang terdapat pada kuadran I dan III karena pada kuadran-kuadran tersebut kemampuan pemecahan masalah matematika berbanding lurus dengan kecemasan matematika siswa. 
Pada kuadran II kemampuan
pemecahan masalah matematika berbanding terbalik dengan kecemasan matematika siswa, kuadran ini sudah sesuai dengan hasil pengujian yang telah dilakukan. Sekolah-sekolah pada kuadran II menggambarkan keadaan dimana siswa-siswa pada sekolah tersebut memiliki kemampuan pemecahan masalah yang rendah serta kecemasan matematika yang tinggi. Sekolah-sekolah yang berdasarkan teori seharusnya mengisi kuadran II adalah sekolah-sekolah yang tidak terakreditasi, yaitu sekolah $\mathrm{M}, \mathrm{N}$, dan O.

Pada kuadran IV kemampuan pemecahan masalah matematika juga berbanding terbalik dengan kecemasan matematika siswa, kuadran ini juga sudah sesuai dengan hasil pengujian yang telah dilakukan. Sekolah pada kuadran IV menggambarkan keadaan dimana siswa-siswa pada sekolah tersebut memiliki kemampuan pemecahan masalah yang tinggi serta kecemasan matematika yang rendah. Sekolah-sekolah yang berdasarkan teori seharusnya mengisi kuadran IV adalah sekolah-sekolah dengan status akreditasi A, yaitu sekolah A, B, C, D, E, F, G, H, dan I.

Sekolah dengan status akreditasi B seperti sekolah J, K, dan L, secara teori masih bisa terdapat pada kuadran II dan IV karena memiliki kemampuan pemecahan masalah dan kecemasan matematika yang menengah, mendekati titik $(0,0)$.

Pembentukan perbandingan seperti pada Tabel 2 bukan tanpa dasar. Adanya pengelompokan sekolah berdasarkan status akreditasi sudah melalui beberapa tahap penilaian. Berdasarkan BAN-SM (2017: 1), komponen akreditasi yang menjadi penilaian terdapat delapan standar yaitu standar isi, proses, kompetensi lulusan, pendidik dan tenaga didik, sarana dan prasarana, pengelolaan, pembiayaan dan penilaian. BAN-SM (2017: 9) menyatakan bahwa sebuah sekolah dinyatakan memiliki status akreditasi A jika sekolah tersebut memiliki nilai total akhir dari seluruh komponen akreditasinya sebesar 91 sampai 100 . Sehingga kecil kemungkinan sekolah dengan nilai yang bagus dalam setidaknya delapan komponen tersebut tidak memiliki kemampuan pemecahan matematika yang tinggi dan kecemasan matematika yang rendah.

Sebuah sekolah dinyatakan memiliki status akreditasi B merupakan sekolah yang nilai akhir dari seluruh komponen akreditasinya sebesar 81 sampai 90, dengan nilai setinggi itu penulis berpikir sekolah dengan akreditasi B lebih cocok berada pada kuadran II tetapi memiliki lebih besar kemungkinan dari sekolah dengan akreditasi A memiliki kemampuan pemecahan masalah yang rendah dan kecemasan matematika yang tinggi.

Sebuah sekolah dinyatakan tidak terakreditasi jika tidak memenuhi kriteria berikut; memperoleh nilai akhir hasil akreditasi sekurang-kurangnya 71 , memperoleh nilai komponen sarana dan prasarana tidak kurang dari 61, dan tidak ada nilai komponen dibawah 50 . Dengan tidak memenuhinya salah satu dari ketiga syarat di atas, maka mungkin hal tersebut menjadi penyebab sekolahsekolah yang tidak terakreditasi memiliki kemampuan pemecahan masalah rendah dan kecemasan matematika yang tinggi.

Selanjutnya akan dibahas mengenai analisis faktor-faktor yang mungkin menjadi penyebab perbedaan letak sekolah pada peta kemampuan pemecahan masalah dan kecemasan matematika antara teori dan fakta pada masing-masing kuadrannya.

\section{8 | AKSIOMA}




\section{Kuadran I}

Sekolah yang berada pada kuadran I yang pertama adalah sekolah $\mathrm{C}$ dengan rata-rata kemampuan pemecahan masalah siswanya adalah 18,00 dan rata-rata kecemasan matematika siswanya adalah 20,77. Sekolah C merupakan sekolah yang termasuk dalam strata satu, artinya sekolah $\mathrm{C}$ memiliki status akreditasi A.

Berdasarkan data-data di atas dapat dilihat beberapa hal yang mungkin menjadi penyebab dari kesenjangan hasil penelitian pada sekolah ini. Kemampuan pemecahan masalah matematika yang tinggi dapat dianggap wajar karena sekolah ini merupakan sekolah dengan akreditasi A sehingga siswa sudah memiliki semua hal yang mereka butuhkan untuk belajar dengan maksimal.

Adapun kecemasan matematika yang tinggi diakibatkan oleh sistem sekolah yang merupakan sekolah asrama dan jumlah siswa dalam satu buah kelas yang terlalu banyak. Sekolah asrama juga memiliki program-program tambahan di waktu tertentu sehingga mengurangi waktu siswa untuk mempersiapkan pembelajaran yang akan datang sehingga meningkatkan kecemasan siswa dalam menghadapi pelajaran matematika. Hal ini didukung oleh pernyataan Dursun (2015: 1779) yang menyatakan bahwa kecemasan matematika akan meningkat pada siswa yang belajar dalam sekolah yang berasrama.

Sekolah yang kedua adalah sekolah E yang juga merupakan sekolah dengan status akreditasi A. Rata-rata kemampuan pemecahan masalah matematika siswa pada sekolah $\mathrm{E}$ adalah 17,35 dan rata-rata kecemasan matematika siswa pada sekolah ini adalah 22,50.
Penyebab tingginya kecemasan matematika di sekolah ini diperkirakan karena sekolah E termasuk sekolah favorit di Kota Banjarbaru yang dapat dilihat dari banyaknya siswa, prestasi dan dengan nilai UN matematika yang tinggi selama tiga tahun berturut-turut yakni 97, 90 dan 100. Dengan adanya capaian ini siswa didorong untuk juga bisa berlomba-lomba memperoleh nilai yang tinggi, namun efek samping dari hal ini adalah timbulnya kecemasan matematika yang tinggi pula.

Selain itu juga dijelaskan oleh Wang et al (2010:1) bahwa pada siswa dengan motivasi intrinsik tinggi, kemampuan pemecahan masalah matematika akan membentuk korelasi $\mathrm{U}$ dengan kecemasan matematika. Maksud dari korelasi U dalam penelitian tersebut, siswa dengan motivasi intrinsik yang sangat tinggi dan sangat rendah sama-sama memiliki kecemasan matematika yang tinggi sementara siswa-siswa yang memiliki motivasi intrinsik menengah memiliki kecemasan matematika yang rendah. Hal ini membuat masuk akal bahwa siswa di sekolah E dan bahkan sekolah $\mathrm{C}$ yang memiliki kemampuan pemecahan masalah yang tinggi juga memiliki kecemasan matematika yang tinggi pula.

\section{Kuadran II}

Kuadran II seharusnya berisi sekolah-sekolah dengan kualitas rendah karena menggambarkan sekolah dengan siswa yang memiliki kemampuan pemecahan masalah rendah dan kecemasan matematika yang tinggi. Uniknya, terdapat tiga buah sekolah dengan akreditasi A yang terdapat dalam kuadran ini. Dalam pembahasan ini hanya akan dibahas mengenai sekolah D, F, H dan L yang diasumsikan memiliki kualitas tinggi. Sekolah M diasumsikan memiliki kualitas yang rendah karena merupakan 
sekolah dengan status tidak terakreditasi.

Sekolah D memiliki rata-rata kemampuan pemecahan masalah 13,79 dan rata-rata kecemasan matematika 21,58. Sekolah D memiliki siswa kelas VIII berjumlah 97 siswa yang terbagi menjadi empat kelas sehingga masingmasing kelas diisi oleh 24 hingga 25 siswa.

Keadaan ekonomi siswa di sekolah ini pun terbilang cukup rendah. Terlihat dari 149 siswa yang terdata bahwa penghasilan keluarganya perbulan di bawah Rp2.000.000, sedangkan hanya 48 siswa penghasilan keluarganya di atas Rp2.000.000. Menurut Geyik (2015: 311), tingkat penghasilan dan pendidikan orangtua siswa berpengaruh pada kecemasan matematika siswa tersebut. Hal ini bisa menjadi faktor mengapa sekolah dengan status akreditasi A ini memiliki kecemasan matematika yang tinggi.

Adanya hubungan antara keadaan orangtua dan kecemasan matematika siswa juga diungkapkan oleh Isabelo dan Silao (2018: 487). Pengaruh yang diberikan orangtua dan lingkungan memang secara tidak langsung mempengaruhi proses pembelajaran di sekolah namun ternyata mampu memberikan pengaruh yang signifikan pada kemampuan pemecahan masalah matematika siswa.

Sekolah selanjutnya adalah sekolah $\mathrm{F}$ yang memiliki rata-rata kemampuan pemecahan masalah 12,54 dan rata-rata kecemasan matematika 22,21. Rata-rata kemampuan pemecahan masalah sekolah $\mathrm{F}$ merupakan yang paling rendah dibandingkan sekolah-sekolah sampel lainnya. Ada perkiraan bahwa faktor pengajar lah yang menjadi penyebabnya.

Pengajar matematika kelas VIII di sekolah $\mathrm{F}$ ini adalah seorang guru laki-laki yang baru memiliki pengalaman mengajar selama tiga tahun. Jam mengajar dalam satu minggu pun hanya 15 jam dan hanya mengajar di sekolah tersebut. Hal yang sejalan juga dinyatakan oleh Pimta et al (2009: 381) bahwa kebiasaan guru juga merupakan salah satu faktor yang mempengaruhi kemampuan pemecahan matematika siswa. Ia menjelaskan bahwa guru harus bisa memempelajari cara agar bisa mengembangkan kemampuan pemecahan masalah matematika yang ada pada diri siswa.

Faktor ini juga yang diperkirakan menjadi penyebab tingginya kecemasan matematika siswa. Selain itu rendahnya kemampuan pemecahan masalah matematika juga ikut menambah tingginya kecemasan yang dirasakan siswa terhadap matematika seperti yang sudah terbukti dalam penelitian ini.

Sekolah selanjutnya adalah sekolah $\mathrm{H}$ yang memiliki rata-rata kemampuan pemecahan masalah sebesar 13,63 dan rata-rata kecemasan matematika siswanya sebesar 25,25. Sekolah H merupakan sekolah dengan rata-rata kecemasan matematika tertinggi dibanding sekolah-sekolah sampel lainnya. Sekolah ini berstatus akreditasi A namun begitu kualitas yang dimiliki tidak menggambarkan sekolah yang baik.

Siswa di sekolah ini hanya berjumlah 30 orang dengan siswa kelas VIII hanya berjumlah 8 orang. Guru yang ada hanya 12 orang dengan hanya 4 orang guru pegawai negeri. Sekolah ini sudah berdiri dari tahun 2008 namun belum bisa meningkatkan keadaan sekolah. Sarana dan prasarana yang ada pun masih kurang memadai, lingkungan sekitar sekolah juga kurang nyaman untuk suasana pembelajaran.

Rendahnya kualitas sekolah ini dimulai dari guru, siswa, lingkungan, 
maupun sarana membuat sangat wajar jika sekolah ini memiliki kemampuan pemecahan masalah yang rendah dan kecemasan matematika yang tinggi. Sebaliknya, yang menjadi pertanyaan adalah bagaimana bisa sekolah $\mathrm{H}$ mendapatkan status akreditasi A.

Sekolah terakhir yang akan di bahas dalam kuadran ini adalah sekolah L. sekolah L merupakan satu-satunya sekolah dengan status akreditasi B dalam kuadran ini. Sekolah B memiliki rata-rata kemampuan pemecahan masalah sebesar 14,79 dan rata-rata kecemasan matematika sebesar 21,11. Sekolah L berada agak jauh dari perkotaan.

Faktor daerah asal mayoritas siswa yang bersekolah di sekolah $\mathrm{L}$ menjadi kemungkinan penyebab rendahnya rata-rata kemampuan pemecahan masalah di sekolah ini. Pernyataan ini didukung oleh hasil penelitian Graham dan Provost (2012: 6) yang menyatakan bahwa siswasiswa yang berasal dari pedesaan memiliki kemampuan matematika awal yang rendah dan mengalami peningkatan kemampuan yang lebih lambat dibandingkan siswa-siswa di perkotaan. Hal ini disebabkan sumber pembelajaran yang lebih sulit didapat oleh siswa-siswa tersebut dan teknologi serta internet yang belum sebanyak dan semudah siswa-siswa perkotaan dapatkan.

Terkait dengan tingginya kecemasan matematika siswa pada sekolah L, Hlalele (2012: 274) menyatakan bahwa siswa dari daerah pedesaan umumnya mengalami kecemasan matematika. Hlalele menyarankan bahwa sekolah harus lebih waspada dalam mengatasi kecemasan matematika yang ada pada sekolah di daerah pedesaan dengan menerapkan berbagai teknik pembelajaran.

\section{Kuadran III}

Sekolah pertama yang terdapat di kuadran III adalah sekolah J. Sekolah J memiliki rata-rata kemampuan pemecahan masalah siswa sebesar 14,54 dan rata-rata kecemasan matematika siswa sebesar 20,77. Sekolah J merupakan sekolah dengan akreditasi B pada daerah yang jauh dari daerah kota. Total siswa kelas VIII di sekolah $\mathrm{J}$ terdapat 50 siswa yang terbagi menjadi dua buah kelas sehingga setiap kelas terdiri dari 25 siswa. Guru-guru pada sekolah J terdapat 23 orang yang terdiri dari 17 guru PNS dan 6 guru honorer. Guru matematika pada sekolah J merupakan guru dengan status PNS dan pendidikan terakhir S2.

Pada pembahasan sebelumnya sudah dijelaskan bahwa wajar jika kemampuan pemecahan masalah siswasiswa di pedesaan lebih rendah karena faktor teknologi dan informasi yang lebih sulit untuk didapakan. Keadaan yang mengherankan adalah rendahnya kecemasan matematika siswa yang pada siswa pedesaan yang kemampuan pemecahan masalahnya rendah.

Salah satu faktor yang mungkin mempengaruhi hal ini adalah tingkat pendidikan guru matematika di sekolah J. Pimta (2009:381) menyatakan bahwa guru harus bisa menangani pembelajaran siswa, mengatur kegiatan siswa di kelas sehingga siswa dapat memiliki antusias dalam belajar, memiliki sikap yang baik terhadap matematika, dan meningkatkan konsentrasi siswa dalam belajar. Pendidikan hingga jenjang S2 tentu membuat guru lebih mendalami teknikteknik dalam menangani pembelajaran siswa, termasuk mengurangi kecemasan siswa terhadap matematika.

Sekolah selanjutnya adalah sekolah $\mathrm{K}$ yang juga merupakan sekolah dengan status akreditasi B. 
rata-rata kemampuan pemecahan masalah siswa pada sekolah $\mathrm{K}$ adalah 15,23 sedangkan rata-rata kecemasan matamatikanya adalah 19,93.

Berdasarkan data-data yang didapatkan, tidak ditemukan kemungkinan penyebab dari kemampuan pemecahan masalah dan kecemasan siswa yang rendah pada sekolah ini. Faktor-faktor yang tidak ditemukan pada dokumen profil sekolah diantaranya kemampuan guru dalam menyelesaikan masalah matematika, strategi pembelajaran yang dilakukan guru, kecemasan matematika yang dimiliki guru, dan lain sebagainya tentu mungkin menjadi penyebab dari keadaan ini.

\section{Kuadran IV}

Kuadran IV seharusnya berisi sekolah-sekolah dengan kualitas tinggi karena menggambarkan sekolah dengan siswa yang memiliki kemampuan pemecahan masalah tinggi dan kecemasan matematika yang rendah. Uniknya, terdapat dua buah sekolah dengan status tidak terakreditasi yang terdapat dalam kuadran ini. Dalam pembahasan ini hanya akan dibahas mengenai sekolah $\mathrm{N}$ dan O. Sekolah A, $\mathrm{B}, \mathrm{G}$ dan I diasumsikan memiliki kualitas yang tinggi karena merupakan sekolah dengan status akreditasi A.

Sekolah N merupakan sekolah swasta dengan rata-rata kemampuan pemecahan masalah sebesar 18,79 dan rata-rata kecemasan matematika sebesar 19,00. Sekolah N memiliki satu buah kelas VIII dengan jumlah siswa sebanyak 24 orang dan jumlah guru sebanyak 15 orang. Beberapa orang guru di sekolah $\mathrm{N}$ merupakan lulusan Al-Azhar University Kairo Mesir namun belum ada satupun guru di sekolah $\mathrm{N}$ yang berstatus PNS.

Kemungkinan faktor yang menjadikan siswa di sekolah $\mathrm{N}$ memiliki kemampuan pemecahan masalah tinggi dan kecemasan matematika yang rendah adalah guru yang memiliki latar belakang pendidikan yang baik. Seperti yang sudah dijelaskan sebelumnya bahwa guru dengan pendidikan yang baik akan mampu mengatur kegiatan pembelajaran siswa di kelas sehingga kemampuan pemecahan masalah siswa dapat ditingkatkan dan kecemasan matematika siswa dapat diminimalkan.

Faktor selanjutnya yang mungkin menjadi penyebab sekolah $\mathrm{N}$ berstatus tidak terakreditasi adalah dikarenakan sekolah $\mathrm{N}$ baru berdiri pada tahun 2013 sehingga belum dapat memenuhi persyaratan untuk mendapatkan status akreditasi.

Sekolah terakhir adalah sekolah $\mathrm{O}$ yang juga berstatus swasta. Sekolah $\mathrm{O}$ memiliki rata-rata kemampuan pemecahan masalah sebesar 18.88 dan rata-rata kecemasan matematika sebesar 19,54. Sekolah O memiliki karakter yang hampir sama dengan sekolah $\mathrm{N}$ dari sisi fasilitas, kualitas guru, dan tahun didirikan. Sekolah O didirikan tahun 2014 sehingga baru 4 tahun beroperasi. Siswa-siswa di sekolah O memiliki prestasi yang banyak dari bidang akademik maupun non akademik.

Faktor yang menyebabkan tingginya kemampuan pemecahan masalah dan banyaknya prestasi pada siswa sekolah $\mathrm{O}$ bisa jadi serupa dengan sekolah $\mathrm{N}$ yaitu latar belakang guru yang mengajar di sekolah tersebut. Penyebab sekolah $\mathrm{O}$ tercatat sebagai sekolah yang tidak terakreditasi mungkin juga sama dengan sekolah $\mathrm{N}$ yaitu karena sekolah $\mathrm{O}$ baru didirikan. Berdasarkan observasi sarana dan prasarana sekolah $\mathrm{O}$ juga sudah sangat layak. Metode pembelajaran yang dilakukan oleh guru di kelas juga beragam, salah satunya dengan menggunakan metode pembelajaran di 
luar kelas. Hal ini tentu mempengaruhi kemampuan pemecahan masalah dan kecemasan matematika siswa.

Pembahasan di atas menyatakan bahwa berdasarkan hasil pemetaan kemampuan pemecahan masalah dan kecemasan matematika, terdapat sangat banyak faktor yang mempengaruhi kemampuan pemecahan masalah dan kecemasan matematika siswa. Hal ini seharusnya membuat kita membuka mata bahwa terdapat sesuatu yang salah dengan cara pandang kita jika menilai sebuah sekolah berdasarkan status akreditasinya saja. Banyak hal lain yang juga penting untuk diperhatikan.

Selain itu hal yang lebih penting disini adalah proses dan instrument penilaian akreditasi yang digunakan untuk memberikan penilaian terhadap sekolah itu sendiri juga perlu dievaluasi kembali. Apakah hasil penilaian yang didapat valid dan menggambarkan keadaan yang sebenarnya atau tidak.

\section{KESIMPULAN DAN SARAN}

Berdasarkan hasil penelitian, dapat ditarik kesimpulan bahwa kemampuan pemecahan masalah matematika dan kecemasan matematika dipengaruhi oleh akreditasi sekolah, misalnya A, B, G, I dan M yang berada pada kuadran yang sesuai dengan status akreditasi sekolahnya.

Adanya pengaruh ini ternyata tidak mutlak karena masih ada sekolah yang memiliki akreditasi A berada pada kuadran II yang seharusnya diisi oleh sekolah dengan status akreditasi rendah. Selain itu masih ada juga sekolah yang tidak sesuai dengan hasil penelitian yang menyimpulkan bahwa tingkat kemampuan pemecahan masalah seharusnya berbanding terbalik dengan tingkat kecemasan matematika.

Tentunya hal ini dipengaruhi bukan hanya dari status akreditasi sekolah, namun juga dari banyak faktor lain, misalnya letak sekolah, status sekolah, motivasi siswa, keadaan ekonomi orangtua, lingkungan sekolah, status guru dan banyak faktor lain yang tidak bisa disebutkan satu per satu. Oleh karena itu sangat diharapkan adanya penelitian untuk meneliti faktor lain yang mempengaruhi kemampuan pemecahan masalah maupun kecemasan matematika.

\section{DAFTAR PUSTAKA}

Pimta S., Tayruakham S. dan Nuangchalerm P. (2009). Factors Influencing Mathematic Problem-Solving Ability of Sixth Grade Students. Journal of Social Sciences. 5 (4), 381-385.

Kramarski, B. (2009). Developing A Pedagogical Problem Solving View for Mathematics Teachers with Two Reflection Programs. International Electronic Journal of Elementary Education, 2(1), 137-153.

OECD. (2016). PISA 2015 Results in Focus. PISA: OECD Publishing.

IEA. (2016). TIMSS 2015 International Results in Mathematics. Downloaded from timss2015.org/download-center.

Mohd N. \& Mahmood, T. (2011). The Effects of Attitude Towards Problem Solving in Mathematics Achievements. Australian Journal of Basic and Applied Sciences, 5 (12), 1857-1862.

Ramirez G., dkk. (2016). On the Relations Between Math Anxiety and Math Achievement in Early Elementary School: The Role of Problem Solving Strategies. Journal of Experimental Child Psychology, 141 (2016), 83-100.

Al Mutawah M.A. (2015). The Influence of Mathematics Anxiety in Middle and High 
School Students Math Achievement. International Education Studies, 8 (11), 239252.

Foley A.E., dkk. (2017). The Math Anxiety-Performance Link: A Global Phenomenon. Current Directions in Psychological Science, 26(1), $52-58$.

Karasel, dkk. (2010). The relationship between mathematics anxiety and mathematical problem solving skills among primary school students. Procedia Social and Behavioral Sciences ,2 (2010), 5804-5807.

Furner J.M. \& Marinas C.A. (2016). Mathematics Anxiety in Society: A Real Phenomena and a Real Solution. Transformations, 1(3), 24-36.

Beilock S.L. \& Maloney E.A. (2015). Math Anxiety: A Faktor in Math Achievement Not to Be Ignored. Policy Insights from the Behavioral and Brain Sciences, 2(1), $4-12$.

BAN-SM. (2017). Perangkat Akreditasi SMP/MTs. Jakarta: Badan Akreditasi Nasional Sekolah/ Madrasah.

Dursun, S. (2015). Investigation of high school students' attitude and anxiety levels towards Mathematics in terms of some variables. Educational Research and Reviews, 10(13), 1773-1780.

Wang Y., \& Chiew V. (2010). On the cognitive process of human problem solving. Cognitive Systems Research, 11(1), 81-92.

Geyik, K. (2015). The Effects of Parents' Socio Economic Status on Mathematics Anxiety Among Social Sciences Students in Turkey. International Journal of Education and Research, 3(1), 311-324.

Isabelo V. \& Silao J. (2018). Factors Affecting the Mathematics Problem Solving Skills of Filipino Pupils: A Study Conducted in Kiamba Central School SPED Center. International Journal of Scientific and Research Publications, 8(2), 487-497.

Graham S. E. \& Provost L. E. (2012). Mathematics Achievement Gaps Between Suburban Students and Their Rural and Urban Peers Increase Over Time. Issue Brief, $52,1-8$.

Hlalele, D. (2012). Exploring rural high school learners' experience of mathematics anxiety in academic settings. South African Journal of Education, 32, 267278. 